\title{
Accuracy and Delay of Using Ultrasound in Testicular Torsion
}

\section{Testis Torsiyonunda Ultrason Kullanımının Doğruluğu ve Gecikmesi}

\author{
(D) Michael Chen 1,2, (D) Rachel Esler1 \\ ${ }^{1}$ Metro North Hospital Health Service, Clinic of Urology, Brisbane, Australia \\ 2 University of Queensland Faculty of Medicine, Brisbane, Australia
}

\section{What's known on the subject? and What does the study add?}

It is known that ultrasound causes a delay in patients with testicular pain going to the operating theatre but no research has quantified this delay. Helping to quantify this data will aid health administrations in outlining policies and guidelines. Furthermore, this data adds to the literature in demonstrating the fairly high accuracy of ultrasound in diagnosing testicular torsion. This study also further highlights the variation in practice in terms of orchidopexy when no torsion is found in theatre and encourages urologists to not perform unilateral orchidopexy and perform bilateral orchidopexy if there is high clinical suspicion.

\section{Abstract}

Objective: Testicular torsion is an emergency which can result in testicular loss. Ultrasounds are controversial due to the delay in time to theatre. Our study aimed to quantify the delays in time to theatre as well as review the correlation between ultrasound and operative findings across the literature. We also review the practice of orchidopexy when testicular torsion was not found.

Materials and Methods: Two years of scrotal explorations were retrospectively reviewed based on electronic medical records. Differences in the time to theatre were calculated using a two-sample t-test. A review of studies analyzing the accuracy of ultrasound in torsion was conducted.

Results: Of the 41 patients included, 10 patients (24.3\%) had testicular torsion. Seventeen patients (41\%) had an ultrasound prior to surgery which resulted in a mean delay of 3 hours and 30 minutes. Our data showed a sensitivity of $100 \%$ and specificity of $92 \%$. A combination of our data with the literature gives a sensitivity of $91.9 \%(n=124 / 135)$ and specificity of $98.9 \%(n=848 / 870)$. In those without torsion, $5(16 \%)$ patients had no orchidopexy performed, 13 (42\%) had unilateral orchidopexy and 13 (42\%) had bilateral orchidopexy performed.

Conclusion: Ultrasound causes significant delays in scrotal exploration which increases the risk of testicular loss. However, despite criticism of its accuracy, ultrasound appears to be highly accurate in the literature and has its use if there is clinical uncertainty. Long-term data is lacking on performing orchidopexy if torsion is not present and clinical practice continues to vary in this area.

Keywords: Ultrasound, Torsion, Delay

\section{Öz}

Amaç: Testis torsiyonu, testis kaybıyla sonuçlanabilecek acil bir durumdur. Operasyon zamanındaki gecikmeden dolayı ultrason kullanımı tartışmalıdır. Çalışmamızda, operasyon zamanında yaşanan gecikmeleri ölçmekle birlikte, literatürdeki ultrason ve operatif bulgular arasındaki ilişkinin gözden geçirilmesi amaçlanmıştır. Ayrıca, testis torsiyonu bulunmadığında orşiopeksi uygulaması gözden geçirilmiştir.

Gereç ve Yöntem: İki yıllık skrotal eksplorasyonlar, elektronik tıbbi kayıtlar baz alınarak retrospektif olarak incelendi. Operasyon zamanındaki farklılıklar, iki örneklem t-testi kullanılarak hesaplandı. Torsiyonda ultrasonun doğruluğunu analiz eden çalışmaların incelemesi yapıldı.

Bulgular: Çalışmaya dahil edilen 41 hastanın 10'unda $(\% 24,3)$ testis torsiyonu mevcuttu. On yedi (\%41) hastaya ameliyat öncesi ultrason yapıldı, bu da ortalama 3 saat $30 \mathrm{dk}$ gecikmeyle sonuçlandı. Verilerimiz \%100 duyarlılık ve \%92 özgüllük göstermiştir. Literatür ile verilerimizin kombinasyonu $\% 91,9(n=124 / 135)$ duyarlılık ve \%98,9 (n=848/870) özgüllük göstermektedir. Torsiyon olmayan hastaların 5'ine (\%16) orşiopeksi uygulanmaz iken, 13 'üne (\%42) tek taraflı orşiopeksi ve diğer 13'üne (\%42) bilateral orşiopeksi uygulanmıştır.

Sonuç: Ultrason skrotal explorasyonda önemli gecikmeye neden olarak testis kaybı riskini arttırır. Bununla birlikte, doğruluğu eleştirilmesine rağmen

Correspondence: Michael Chen MD, Metro North Hospital Health Service, Clinic of Urology; University of Queensland Faculty of Medicine, Brisbane, Australia

Phone: +6 1416651686 E-mail: michaelyuechengchen@hotmail.com ORCID-ID: orcid.org/0000-0001-8294-6876

Received: 03.05 .2019 Accepted: 23.07 .2019

Cite this article as: Chen M, Esler R. Accuracy and Delay of Using Ultrasound in Testicular Torsion. J Urol Surg 2019;6(4):273-277.

๑Copyright 2019 by the Association of Urological Surgery / Journal of Urological Surgery published by Galenos Publishing House. 
ultrason, literatürde oldukça doğru gibi görünmektedir ve klinik belirsizlik varsa kullanılmaktadır. Torsiyon mevcut değilse orşiopeksi yapılmasına dair uzun dönem veriler eksiktir ve klinik uygulama bu alanda değişmeye devam edecektir.

Anahtar Kelimeler: Ultrason, Torsiyon, Gecikme

\section{Introduction}

Testicular torsion is a urological emergency caused by twisting of the spermatic cord which can result in testicular loss and effects on fertility. This pathology occurs most commonly in neonates and postpubertal boys although can affect males of any age (1). The priority is to proceed to scrotal exploration as soon as possible to reduce the risk of testicular loss (2).

If the diagnosis is unclear, Doppler ultrasound can be used to confirm the diagnosis however is likely to delay the operation and is frequently described in the literature as being inaccurate (3). If evidence of torsion is found during surgery, orchidopexy of both testes is performed (4). However, if torsion is not present there is no consensus as to whether or not orchidopexy is indicated.

This study aims to quantify the time delay caused by ultrasound to aid in decision making for surgeons. In addition, we combine our data with the current literature to quantify the accuracy of ultrasound. We also review the current practice at our center in terms of orchidopexy when testicular torsion is not found and delays caused by inter-hospital transfer between hospitals.

\section{Materials and Methods}

Records of all patients who had scrotal explorations at the Royal Brisbane and Women's Hospital in Queensland, Australia were collected by using the Operating Room Management Information System. Ethics approval was given by the Royal Brisbane and Women's Hospital ethics review board (approval number: HREC|17|QRBW|608). The patients were filtered by the following ICD-10 codes based on operations performed in the years 2015 and 2016:

- Exploration of scrotal contents with fixation of testis, bilateral (ICD-10: 37604-05),

- Exploration of scrotal contents with fixation of testis, unilateral (ICD-10: 37604-04),

- Exploration of scrotal contents, bilateral (ICD-10: 37604-01),

- Exploration of scrotal contents, unilateral (ICD-10: 37604-00),

- Reduction of torsion of testis or spermatic cord (ICD-10: 90399-00).
The electronic medical records of these patients were then reviewed to collect further data. All data was collected by a single researcher with clinical experience in urology. Patients who had scrotal explorations in cases where testicular torsion was not a differential such as for abscess were not included.

The outcome of interest was whether torsion was found intraoperatively and whether an orchidectomy was required. This was judged based on the surgeon's operation report. Another variable of interest was the time taken for the patient to be taken to theatre. This was calculated by subtracting the arrival time of the patient in the emergency department from the time documented as the operation commencing.

Independent variables collected included details on whether an ultrasound was performed, details of orchidopexy performed in the operative report, and whether the patient was transferred from another hospital. Determining whether an ultrasound was positive or negative was based on the radiologist's report. Any findings of decreased or altered blood flow, or reports of potential torsion, were considered as positive results.

Proportions were reported for simple categorical variables such as whether orchidopexy was performed. Differences in time to theatre between groups were calculated by using a two-sample t-test.

\section{Results}

A total of 51 patients were found using the ICD-10 codes described above. Ten patients were excluded as testicular torsion was not a differential diagnosis in their scrotal exploration, for a total of 41 patients.

Ten of these patients had evidence of torsion (24.3\%) with only one of these patients having an orchidectomy (10.0\%). This patient had a time to theatre of 3 hours 27 minutes (207 minutes) and had an ultrasound prior, however, his presentation to the emergency department was delayed by over 8 hours.

The use of ultrasound in $17(41 \%)$ patients resulted in a mean delay of 3.5 hours ( 210 minutes) in the time to theatre $(p<0.001)$ (Table 1). Patients who had to be transferred from a nearby hospital had a mean delay of 1 hour 56 minutes (116 minutes), however as there were only seven patients, this finding was not statistically significant $(p=0.09)$ (Table 1$)$. Five of the 17 ultrasounds performed were suggestive of torsion and 4 of these were confirmed as torsion intraoperatively. No torsion was 
found intraoperatively in 12 patients with negative ultrasounds who went on to have exploration. Based on this, the calculated sensitivity was $100 \%$ and specificity $92 \%$.

Thirty-one patients did not have torsion found during the scrotal exploration. $5(16 \%)$ of these patients had no orchidopexy performed, 13 (42\%) had unilateral orchidopexy and 13 (42\%) had bilateral orchidopexy performed.

\section{Discussion}

This data shows that the delay caused by patients having scrotal ultrasounds is on average 3.5 hours (210 minutes). The ultrasound examination itself can be performed quickly but contributes to significant delay due to sonographer availability, transfer to medical imaging and other logistical delays and our data suggests that it may double the time to the operating theatre. To our knowledge, this is the first study to quantify the delay in time to theatre caused by ultrasound. However, there is potential confounding in our data. For example, if there are delays for other reasons such as clinician or theatre unavailability, then it seems reasonable that an ultrasound be performed in these cases, and in that case ultrasound would not be the cause for the delay. In addition, in some centers, Doppler ultrasound can be performed at the bedside by clinicians experienced in its use and clinical processes may vary. Our data on delay from ultrasound cannot be extrapolated to all centers but provides an indication of the overall effect.

The goal for time to theatre from the onset of pain is usually quoted as 6 hours (5). Some literature suggests that the testis suffers irreversible damage after 12 hours of ischemia from torsion. One study showing this was by Dunne and O'Loughlin (2) which showed that testicular loss rate was 67\% after 12 hours compared to $23 \%$ overall. However, Pogorelic et al. (6) reviewed 558 patients and found the median duration of symptoms resulting in orchidectomy was 46 hours compared

Table 1. Delay in time to theatre based on whether patients had an ultrasound or were transferred from another hospital

\begin{tabular}{|c|c|c|}
\hline & n (\%) & $\begin{array}{l}\text { Time to theatre in } \\
\text { minutes }(95 \% \mathrm{Cl})\end{array}$ \\
\hline \multicolumn{3}{|c|}{ Ultrasound $(p<0.001)^{a}$} \\
\hline Yes & $17(41 \%)$ & $382(246-519)$ \\
\hline No & $24(59 \%)$ & $172(136-208)$ \\
\hline Difference & - & $210(94-326)$ \\
\hline \multicolumn{3}{|c|}{ Inter-hospital transfer $(p=0.09)^{a}$} \\
\hline Yes & $7(17 \%)$ & $355(122-589)$ \\
\hline No & $34(83 \%)$ & $234(171-308)$ \\
\hline Difference & - & $116(57-288)$ \\
\hline
\end{tabular}

to 6 hours in those with salvaged testes. Therefore, a goal of exploration within 6 hours seems an appropriate target and in this context, a 3.5 hour delay with the use of ultrasound could increase the risk of testicular loss.

Ultrasound for testicular torsion is often described as inaccurate, for example, with concerns that residual venous flow within the scrotum may give a false negative when torsion is present (3). Our data suggests a sensitivity of 100\% and specificity of 92\% which is similar to other studies in the literature. Table 2 demonstrates our review of other studies in the literature with regards to specificity and sensitivity of Doppler ultrasound in testicular torsion when compared to operative findings with most studies showing high sensitivity and specificity $(7,8,9,10,11,12,13,14)$. A combination of our data with the literature suggests a sensitivity of 91.9\% ( $n=124 / 135)$ and specificity of $98.9 \%(n=848 / 870)$. In our experience, clinicians underestimate the accuracy of ultrasound for diagnosing testicular torsion which should be utilized if the diagnosis of torsion is uncertain.

Our data also shows a significant variation in clinical practice of orchidopexy when testicular torsion is not present. The longterm consequences of testicular orchidopexy are unclear. There is evidence that orchidopexy, when done for cryptorchidism, can result in testicular atrophy with an incidence of around 8\% $(n=111 / 1400)(15)$. There is also theoretical concern that scrotal or testicular interventions may lead to production of antisperm antibodies which may impact fertility, however, limited evidence exists in the literature. One study followed 8 patients following exploration for testicular trauma and found that only one patient developed antisperm antibodies (16). There is no data in the literature to suggest a benefit to orchidopexy when torsion is not found, but there is theoretical benefit in preventing future or intermittent torsion. Our suggestion is that bilateral orchidopexy is beneficial if history and examination are concerning for torsion but if clinical suspicion is low, then no orchidopexy is needed. Unilateral orchidopexy should not be

Table 2. Sensitivity and specificity of Doppler ultrasound in diagnosing testicular torsion

\begin{tabular}{|l|l|l|}
\hline & Sensitivity (n) & Specificity (n) \\
\hline Wilbert et al. (7) & $82 \%(9 / 11)$ & $100 \%(29 / 29)$ \\
\hline Al Mufti et al. (8) & $100 \%(22 / 22)$ & $97 \%(33 / 34)$ \\
\hline Baker et al. (9) & $88.9 \%(16 / 18)$ & $98.8 \%(83 / 84)$ \\
\hline Kravchik et al. (11) & $88.9 \%(16 / 18)$ & $90 \%(18 / 20)$ \\
\hline Lam et al. (12) & $69.2 \%(9 / 13)$ & $100 \%(319 / 319)$ \\
\hline Liang et al. (13) & $100 \%(29 / 29)$ & $97.9 \%(232 / 237)$ \\
\hline Boettcher et al. (10) & $91.7 \%(11 / 12)$ & $87 \%(80 / 92)$ \\
\hline Agrawal et al. (14) & $100 \%(8 / 8)$ & $100 \%(42 / 42)$ \\
\hline Chen et al. & $100 \%(4 / 4)$ & $92 \%(12 / 13)$ \\
\hline Total combined & $91.9 \%(124 / 135)$ & $97.5 \%(848 / 870)$ \\
\hline
\end{tabular}


performed because if torsion is suspected then the contralateral side is at future risk.

Inter-hospital transfer has been previously discussed as a potential area for improvement in time to theatre for testicular torsion (17). However, another study that reviewed 2.794 cases of torsion of which 2\% had inter-hospital transfer found that transfer was not associated with a higher risk of orchidectomy (18). $17 \%(n=7)$ of patients in our center were transferred from other hospitals which resulted in a mean delay in time to theatre of 1 hour and 56 minutes (116 minutes). Transfer of patients can be controversial in situations where the patient is under 18 years of age or when a local hospital has only general surgical but not urological cover. Interestingly, multiple studies have shown that general surgeons are more likely than urologists to perform orchidopexy when torsion is not present potentially reflecting a difference in training $(19,20)$. Overall, given the time critical nature of the condition, we advocate for prompt scrotal exploration and reserving inter hospital transfer only for when no appropriately trained clinician is present.

\section{Study Limitations}

An important limitation of this study is that only patients who proceeded to scrotal exploration were included, while patients who had ultrasound scans but were discharged home were not included. However, one of the advantages of ultrasound is to prevent the need for patients to have scrotal explorations, and prospective data examining all patients presenting with testicular pain would quantify the benefit ultrasound provides to this cohort. Although the sample size of our cohort was limited, the combination of our data with results in the literature combines for compelling evidence on the accuracy of ultrasound in testicular torsion.

\section{Conclusion}

Ultrasound causes a significant delay which can increase the risk of testicular loss in torsion, however, the literature suggests that it is a fairly accurate diagnostic tool if the clinical picture is uncertain. If clinical history and examination is suggestive of torsion, then prompt exploration without ultrasound is preferred. There remains significant variation in the practice of orchidopexy when testicular torsion is not found. Long term prospective data could lead to consensus guidelines for orchidopexy and further quantify the benefit of ultrasound to patients presenting with testicular pain.

\section{Ethics}

Ethics Committee Approval: Ethics approval was given by the Royal Brisbane and Women's Hospital ethics review board (approval number: HREC $17 \backslash$ QRBW|608).
Informed Consent: Consent form was filled out by all participants.

Peer-review: Externally peer-reviewed.

\section{Authorship Contributions}

Concept: M.C., R.E., Design: M.C., R.E., Data Collection or Processing: M.C., Analysis or Interpretation: Literature Search: M.C., Writing: M.C., R.E.

Conflict of Interest: No conflict of interest was declared by the authors.

Financial Disclosure: The authors declared that this study received no financial support.

\section{References}

1. Molokwu CN, Somani BK, Goodman CM. Outcomes of scrotal exploration for acute scrotal pain suspicious of testicular torsion: a consecutive case series of 173 patients. BJU Int 2011;107:990-993.

2. Dunne PJ, O'Loughlin BS. Testicular torsion: time is the enemy. Aust N Z J Surg 2000;70:441-442.

3. Bandarkar AN, Blask AR. Testicular torsion with preserved flow: key sonographic features and value-added approach to diagnosis. Pediatr Radiol 2018;48:735-744.

4. Pearce I, Islam S, Mclntyre IG, O'Flynn KJ. Suspected testicular torsion: a survey of clinical practice in North West England. J R Soc Med 2002;95:247249.

5. Kapoor S. Testicular torsion: a race against time. Int J Clin Pract 2008;62:821827.

6. Pogorelic Z, Mustapic K, Jukic M, Todoric J, Mrklic I, Messtrovic J, Jurić I, Furlan D. Management of acute scrotum in children: a 25-year single center experience on 558 pediatric patients. Can J Urol 2016;23:8594-8601.

7. Wilbert DM, Schaerfe CW, Stern WD, Strohmaier WL, Bichler KH. Evaluation of the acute scrotum by color-coded Doppler ultrasonography. J Urol 1993;149:1475-1477.

8. al Mufti RA, Ogedegbe AK, Lafferty K. The use of Doppler ultrasound in the clinical management of acute testicular pain. Br J Urol 1995;76:625-627.

9. Baker LA, Sigman D, Mathews RI, Benson J, Docimo SG. An analysis of clinical outcomes using color doppler testicular ultrasound for testicular torsion. Pediatrics 2000;105:604-607.

10. Boettcher M, Krebs $T$, Bergholz R, Wenke K, Aronson D, Reinshagen K. Clinical and sonographic features predict testicular torsion in children: a prospective study. BJU Int 2013;112:1201-1206.

11. Kravchick S, Cytron S, Leibovici O, Linov L, London D, Altshuler A, Yulish E. Color Doppler sonography: its real role in the evaluation of children with highly suspected testicular torsion. Eur Radiol 2001;11:1000-1005.

12. Lam WW, Yap TL, Jacobsen AS, Teo HJ. Colour Doppler ultrasonography replacing surgical exploration for acute scrotum: myth or reality? Pediatr Radiol 2005;35:597-600.

13. Liang T, Metcalfe P, Sevcik W, Noga M. Retrospective review of diagnosis and treatment in children presenting to the pediatric department with acute scrotum. AJR Am J Roentgenol 2013;200:444-449.

14. Agrawal AM, Tripathi PS, Shankhwar A, Naveen C. Role of ultrasound with color Doppler in acute scrotum management. J Family Med Prim Care $2014 ; 3: 409-412$ 
15. Ein $\mathrm{SH}, \mathrm{Nasr} A$, Wales $\mathrm{PW}$, Ein $\mathrm{A}$. Testicular atrophy after attempted pediatric orchidopexy for true undescended testis. J Pediatr Surg 2014;49:317-322.

16. Kukadia AN, Ercole CJ, Gleich $\mathrm{P}$, Hensleigh $\mathrm{H}$, Pryor JL. Testicular trauma: potential impact on reproductive function. J Urol 1996;156:1643-1646.

17. Lodwick DL, Cooper JN, Minneci PC, Deans KJ, McLeod D. Factors affecting pediatric patient transfer in testicular torsion. J Surg Res 2016;203:40-46.

18. Yiee JH, Lynne Chang AB, Kaplan A, Kwan L, Chung PJ, Litwin MS. Patterns of Care in Testicular Torsion: Influence of Hospital Transfer on Testicular Outcomes. J Pediatr Urol 2013;9:713-720.

19. Naumann DN, Jones SA, Taylor C, Jaganathan R, Hendrickse CW, Karandikar S. Heterogeneity in practice during negative scrotal exploration for clinically-suspected testicular torsion. Surgical Practice 2015;19:64-68.

20. Tydeman C, Davenport K, Glancy D. Suspected testicular torsion - urological or general surgical emergency? Ann R Coll Surg Engl 2010;92:710-712. 